\title{
Omsk hemorrhagic fever
}

INSERM

\section{Source}

INSERM. (1999). Orphanet: an online rare disease and orphan drug data base. Omsk hemorrhagic fever. ORPHA:319266

Omsk hemorrhagic fever (OHF), caused by Omsk hemorrhagic fever virus (OHFV), is a zoonotic disease characterized by fever, nausea, myalgia and moderately severe hemorrhagic manifestations as well as in some cases mening itis, pneumonia and nephrosis. 